\title{
Preliminary Study of the Ideological and Political Theories Teaching in the Floriculture Course Based on the Online Course Platform
}

\author{
Jing $\mathrm{Wu}^{*}$, Zenghui Hu, Kezhong Zhang, Yazhou Zhao \\ College of Landscape Architecture, Beijing University of Agriculture, Beijing 102206, China \\ *Corresponding author. Email: Jing Wu, wjmxy1988@ 126.com
}

\begin{abstract}
"Ideological and political theories teaching in all courses" refers to the integration of moral education into the courses, which emphasizes the organic combination of knowledge transfer and value guidance. It is an inevitable choice for higher education to realize the whole process and all-round education. By analyzing the application of online course platform in the teaching of Floriculture and the necessity of ideological and political theories teaching in Floriculture course for landscape architecture majors, this paper fully explores the ideological and political elements contained in the Floriculture course, starting from combing ideological and political elements to carry out the teaching reform of Floriculture course, so as to provide reference for ideological and political education of landscape majors.
\end{abstract}

Keywords: Online courses Floriculture, Ideological and political theories teaching in all courses Exploration.

\section{INTRODUCTION}

College students are the hope of the motherland and the future of the nation. The fundamental task of universities is to "strengthen moral education and cultivate people", and the improvement of the quality of talent training is inseparable from classroom teaching. In 2016, General Secretary Xi emphasized at the National Conference on Ideological and Political Work in Colleges and Universities that it is necessary to adhere to the central link of strengthening moral education and cultivating people, to make good use of the main channel of classroom teaching, to strengthen ideological and political theory courses through improvement, and to enhance the affinity and pertinence of ideological and political education to meet the needs and expectations of growth and development of the students [1]. Colleges and universities should fully excavate the elements of the ideological and political theories teaching in all courses, make the education of ideological and political theories teaching in all courses play a role [2], and cultivate socialist successors with comprehensive development of morality, intelligence, beauty, sports, and labor.

The landscape architecture major of Beijing University of Agriculture has been selected as the national first-class undergraduate major construction site in 2020, and "Floriculture" is the professional core course of landscape architecture major (64 credit hours), and it occupies an important position in the undergraduate teaching of landscape architecture, which is a highly practical course. On the basis of the courses of Botany, Plant Physiology and other courses, Floriculture systematically introduces the basic knowledge of flower classification and flower cultivation facilities, basic theories such as the relationship between the main ecological factors and growth and development in flower cultivation, and the basic knowledge and skills of flower reproduction, cultivation management and application, etc. Focus on the identification points, main ecological habits, cultivation techniques and application characteristics of all kinds of important flowers. The students can master the theoretical knowledge and skills of flower classification, identification points, ecological habits, management and application of reproduction and cultivation through the course study, which lays a foundation for the study of urban green space planning and other courses, and lays a foundation for future flower reproduction, production, conservation and landscape application in the garden industry. 
As the tide of teaching reform continues to rise in recent years, the teaching of Floriculture at Beijing University of Agriculture has also carried out exploratory reforms, trying to introduce new teaching concepts and methods into the classroom, however, there are still many problems. Mainly including: The teaching method is single and outdated, the teacher-student interaction is not enough, the teaching is still mainly based on the lecture of teachers with low student participation; The teaching class hour is not enough and it cannot meet the requirements of training objectives, which makes teachers more ignorant of ideological and political content, and only focus on the teaching of textbook knowledge; There are so many students, so the teachers cannot teach students in accordance with their aptitude, and the teaching effect is not satisfactory; Students lack the initiative and consciousness of learning, and they do not have a firm grasp of knowledge, etc.

\section{THE APPLICATION OF ONLINE COURSE PLATFORM IN THE TEACHING OF FLORICULTURE}

With the advancement of science and technology and the development of the information age, Internet technology is developing rapidly and the scale is constantly expanding. Education in China has entered the era of intelligent education with rich and diverse learning methods and open and shared resources at this stage. In the context of "Internet + Education" [3-4], online course education with new teaching models is generally carried out in colleges and universities, such as Rain Classroom, MOOC, Zhihuishu and other platforms. During the outbreak of COVID-19 in 2020, colleges and universities all over the country carried out online teaching activities of "class suspension and non-stop learning", using online teaching platforms and tools, through online teaching platforms, students completed course learning. In 2020, online education comprehensive platform course center was launched in Beijing University of Agriculture. Through the platform, teachers can publish teaching videos, related learning materials, design expansion tasks, and release test questions on the platform. Students use the teaching resources on the platform to learn independently; Classroom teaching carries out Q\&A and discussion and exchange, and can answer questions in real time on the platform, so as to know the learning situation of students in time and adjust the learning progress. Through the three stages of pre-class, in-class and after-class, students' initiative in learning are motivated and the teaching effect is improved. In addition, teachers can use online course platforms such as MOOC and iCourse to push interesting knowledge of Floriculture to students, so that students can absorb meaningful knowledge of flowers and enhance their sense of mission in learning Floriculture.

\section{THE NECESSITY OF IDEOLOGICAL AND POLITICAL THEORIES TEACHING IN FLORICULTURE COURSE FOR LANDSCAPE ARCHITECTURE MAJORS}

College students must not only receive systematic professional knowledge and skills education during the university period, but also receive ideological and political education. The teaching reform of ideological and political theories teaching in all courses must go deep into each professional course. We should promote the ideological and political education of professional courses, effectively design and implement the teaching objectives, teaching contents and teaching methods in the teaching of professional courses, give full play to the value penetration effect of professional courses and the value guiding role of college students, and strengthen the organic combination of "four-in-one" (knowledge imparting, ability training, value shaping and personality improvement). Floriculture is the core course of landscape architecture major, which plays an important role in the construction of Beautiful China. Its content involves the coexistence of ornamental, practical, scientific and artistic features [5], which conforms to the ecological civilization thought and socialist core values in China [6]. Meanwhile, the elements of Chinese history, flower culture, and workplace spirituality can also be deeply integrated into the courses. Not only require students to have professional knowledge of flower reproduction, cultivation and application, but also need to have a certain cultural literacy and aesthetic ability. Inject ideological and political elements into the various teaching links of the course, strengthen moral education and cultivate people with teaching and education simultaneously. Cultivate the feelings of independent thinking, unity and cooperation, bearing hardships and standing hard work, cherishing posts and devoting wholeheartedly to work for students of landscape architecture majors, raise students' awareness of loving landscape architecture majors and the flower industry, enhance their love for nature, protect the ecology, and enhance the responsibility and awareness of promoting the development of the flower industry in our country.

The integration of ideological and political content in professional courses is beneficial to emphasizing that all teachers have the responsibility of educating people, and all courses have the function of educating people. Teachers are the implementers of teaching and educating people, the disseminators of advanced culture and supporters of the principles and policies of the Party. Teachers should be good guides for students to temper their character, innovate their thinking, learn knowledge and devote themselves to the motherland with their solid professional knowledge, rigorous scientific attitude and tireless teaching spirit. The Floriculture course is highly professional and practical. 
In addition to teaching and scientific research, teachers should also serve the society. Thus teachers should always keep learning status, stand at the forefront of the development of the era, constantly improve their professional knowledge and strengthen teaching management, sort out the ideological and political elements contained in Floriculture courses, integrate them into all links of classroom teaching, help and guide students in all aspects.

\section{IMPLEMENTATION APPROACHES OF INCORPORATING IDEOLOGICAL AND POLITICAL ELEMENTS INTO FLORICULTURE BASED ON THE ONLINE COURSES}

\subsection{Revise the talent training scheme for landscape architecture majors and the syllabus of Floriculture with ideological and political content added.}

In the context of the transformation, the landscape architecture major of Beijing University of Agriculture re-formulated the training scheme. Due to Floriculture is the basic professional course. In order to adapt to the transformation of the school, 24 hours of experimental courses have been added. The development of the 2020 version of the course syllabus is based on the Opinions on Accelerating the Construction of High-level Undergraduate Education and Comprehensively Improving the Ability to Cultivate Talents that the Ministry of Education issued and the connotation of the construction of new agricultural sciences. Focusing on the overall implementation of the fundamental task of "strengthen moral education and cultivate people" and the teaching concept of "student-centered, output-oriented, and continuous improvement", it is closely linked to the Training Scheme for Undergraduate Professional Talents in Beijing University of Agriculture (2020 version), and has made great improvements and innovations on the basis of the syllabus of the 2016 version of the course syllabus. Under the guidance of the concept of "ideological and political theories teaching in all courses", the Floriculture was revised, the original quality objectives were integrated with moral education elements and materials, the teaching design was done well, and all links of classroom teaching were organically integrated to realize the effective unity of ideological and political education and professional knowledge system education, which shall cultivate the good ideological and political study habits of students, guide students to set up socialist core values, cultivate their sense of responsibility and mission, and realize internalization of professional knowledge and sublimation of moral sentiment.

\subsection{Excavate the ideological and political correspondence of this course and build the ideological and political resources of this course.}

Keep pace with the times and use online resources to establish a mixed teaching model of video learning, classroom instructions, and online group discussions to deepen the education effect of ideological and political theories teaching in all courses. The infiltration learning process of ideological and political content is a learning process that cultivates students to independently conduct ideological and political thinking. Therefore, there is great significance to explore and establish a teaching model integrating "value shaping, knowledge instructions, and ability training" [7].

Value shaping is the enlightenment stage of ideological and political theories teaching in all courses, and the learning of knowledge is supported by beliefs and feelings. The implementation of this stage is mainly based on instructive teacher teaching and students' extended thinking, learning and discussion. Before and after class, teachers guide students to collect information on the current situation of flower resources in our country, the history of the development of the flower industry, the status of the flower industry in people's lives, and the economic value of flowers, etc., and watch documentaries related to flowers through network resources. Through learning and guiding students to love nature, love flower work, enhance students' professional identity and sense of pride, motivate their self-confidence in learning professional knowledge and a sense of responsibility to revitalize the flower industry in our country. And exchange and discuss, broaden their thinking and vision, dare to set up the belief of "big self", and strive to build Beautiful China.

Ideological and political elements are incorporated into the professional knowledge teaching process, the scientific spirit is penetrated into the professional knowledge teaching, which shall realize the unity of knowledge instruction and value guidance. At this stage, the teaching is mainly based on the lecture of teachers, and theoretical knowledge is combined with actual cases as much as possible. In this process, the "humanistic spirit" and "honest morality" with Chinese traditional culture as the core are carried forward. Combining with the flower's own attributes, the ideological and political elements such as "scientific spirit" and "ecological protection" with the cultivation of scientific literacy as the core are constructed. For example, there are abundant flower varieties and various application forms, which guide students to evaluate things objectively; Cultivate patriotic sentiment by introducing flower cultivation culture; Cultivate honesty and ethics by investigating flower production and sales through internships. With the rapid development of today's society, new flower varieties, cultivation techniques, 
application forms, and industrial management models are changing quickly. Teachers need to guide students to pay attention to the development of the industry and cultivate the spirit of reform and innovation. During the teaching process, teachers can use the online platform to provide students with flower pictures, flower applications, flower production facilities, cultivation substrates, and other pictures and flower production technology videos, etc.

Ability training puts professional knowledge and ideological and political theory into practice in the actual process, and realizes the combination of theory and practice. During the process of Floriculture experiments and internships, students will have a deeper understanding and perception of the knowledge they have learned, and organize them into reports for writing and discussion. For example, the flower cutting propagation experiment, through grouping, students design experiments, operations, cultivation management, observation statistics, writing experiment reports, etc., which increase the interest of the content, cultivate students' practical ability and teamwork consciousness, and improve labor quality and physical fitness and psychological quality; Improve the consciousness of innovation and entrepreneurship through internships and case teaching. Encourage students to develop innovative and entrepreneurial projects with the theme of "Science and Technology Helping Agriculture", in order to enable students to better understand the importance of Floriculture, improve students' learning motivation, enhance their consciousness of serving rural revitalization, and exercise their ability to serve rural revitalization.

\subsection{Deepen the teaching content of ideological and political theories teaching in Floriculture courses}

The Floriculture course system includes two parts: general and monographs. The purpose of teaching is to enable students to master the basic theories and skills of flower classification, reproduction, cultivation, management and application, in order to lay a foundation for flower reproduction, production, conservation and landscape application in the garden industry in the future, and integrates ideological and political content in various forms in teaching. I. Increase case teaching. The research object of Floriculture is flowers and the application of flower landscape can be seen everywhere in life. The case of flower landscape design in urban greening is naturally integrated as an ideological and political element. By comparing the development of flower application in China for decades, students can experience the rapid development brought about by reform and opening-up in our country, and enhance "four self-confidences". II. The introduction method of scientists' deeds in the field of flowers. The dual classification of flower varieties was put forward by Mr. Junyu CHEN, a famous academician of flowers. When explaining relevant content, teachers can introduce Mr. Chen's contribution to the flower industry to deepen students' impression of professional knowledge and encourage students to inherit the fine tradition and national spirit of daring to innovate and patriotism. III. Thematic discussion method. In the discussion, cultivate students' professional ethics of teamwork, and the responsibility to bear during discussion. In addition, various teaching methods, such as emotion introduction, question introduction and contrast teaching method, can be used to fully arouse students' learning enthusiasm and creativity.

\section{CONCLUSIONS}

In conclusion, when teachers carry out ideological and political theories teaching in the course of teaching, teachers should carefully excavate the ideological and political elements of the course, deepening the teaching content, and adopt appropriate teaching methods to integrate professional knowledge with ideological and political education, which enable students to internalize the ideological and political content in their hearts, externalizing it in their actions, and make it practical, in order to educate people in the whole process and in all aspects, which is of great significance to cultivate high-quality compound talents with "both ability and political integrity".

\section{ACKNOWLEDGMENTS}

This work was supported by Cross training of high-level talents in Colleges and universities in Beijing 'Practical training plan' project (PXM2020_014207_000009), Forestry Professional Training Teaching Team Project, and Construction fund of first class Landscape Architecture Specialty.

\section{REFERENCES}

[1] Jinping XI. Put Ideological and Political Work Through the Whole Process of Education and Teaching to Create a New Situation for the Development of Higher Education in Our Country [N]. People's Daily, December 9, 2016

[2] Huiqun CAO. The Core Elements and Realization Methods of "Ideological and Political Courses" in Colleges and Universities [J]. Journal of Anqing Normal University (Social Science Edition), 2020, 39(4): 5 .

[3] Maoli QIN. Studies on the Use of Online Courses by Local College Teachers and Its Influencing Factors [D]. Chongqing: Chongqing Normal University, 2016. 
[4] Xin JIANG. Discussion on the Practice and Reform of Online Course Construction Mode in Colleges and Universities $[\mathrm{J}]$. Modern Educational Technology, 2017 (11): 1.

[5] Pan DONG and Maozhi REN. Exploration on the Application of the "four principles" in the Course of "Landscape Floriculture" [J]. South China Agriculture, 2021, 15 (13): 79-81.

[6] Min ZHANG. Studies on the Ideological and Political Theories Teaching in Garden Plants and Planting Design Course Which is Deeply Rooted in the Socialist Core Values [J]. Tea in Fujian, 2020, 42 (01): 215.

[7] Wenshu WANG. Promote the Reform and Innovation of Teaching Mode to Build the Top Graduate Ideological and Political Theory Courses in China $[\mathrm{J}]$. Studies in Ideological Education, 2016, (12): 45-48. 